Journal of African Economies, Volume 16, Number 5, pP. 745-781 doi:10.1093/jae/ejm014 online date 6 August 2007

\title{
Fiscal Renaissance in a Democratic South Africa
}

\author{
Tania Ajam ${ }^{\mathrm{a}, *}$ and Janine Aron ${ }^{\mathrm{b}}$ \\ ${ }^{a}$ AFReC (Pty) Ltd, South Africa and \\ ${ }^{\mathrm{b}}$ Department of Economics, Oxford University
}

South Africa has overcome adverse initial conditions to achieve a remarkable fiscal transformation since the 1994 democratic elections, held amid uncertainty about its ability to maintain the rule of law and resist populist spending pressures. Constitutionally based, durable and credible fiscal reforms have contained spending and rendered policy at all levels of government more transparent and accountable, and more predictable through multi-year budgeting. Extensive tax reform and more efficient tax collection have expanded revenue, permitting lower tax rates for both individuals and companies, and personal tax relief. Fiscal consolidation almost eliminated the budget deficit by 2005, and with improved debt management, has created a lower and more sustainable debt burden. While highly centralised revenue-raising powers and greater decentralisation of expenditure to sub-national governments created a vertical fiscal imbalance, a strict no-bail-out approach helped control provincial spending. The fiscal-monetary policy mix has stabilised the macroeconomy and reduced uncertainty, reflected internationally in narrowed sovereign risk spreads and improved debt ratings. However, microservice delivery in social expenditure has been disappointing (in some cases owing to capacity constraints rather than inadequate fiscal allocations), and a long-term decline in infrastructure investment and capital stock is only belatedly receiving attention. The challenge is to increase social and infrastructure expenditure at a sustainable rate and to improve the quality of service delivery, to avoid undermining the gains in macroeconomic stability.

JEL Classification: E62, H11, H50, H60, H70

* Corresponding author: Tania Ajam, AFReC (Pty) Ltd, South Africa, E-mail: tajam@afrec.co.za

(C) The author 2007. Published by Oxford University Press on behalf of the Centre for the Study of African Economies. All rights reserved. For permissions, please email: journals.permissions@oxfordjournals.org 


\section{Introduction}

The democratically elected African National Congress government assumed office in April 1994 amid great uncertainty about its ability to maintain the rule of law and resist unsustainable policies in the face of populist pressures. While dealing with the aftermath of the Apartheid era, it embarked simultaneously on a socioeconomic transformation project in the spirit of the new Constitution. Inherited fiscal conditions presented a rather bleak picture. There had been some moves towards broadening the tax base, but nevertheless, aggregate fiscal discipline was weak. Escalating government expenditure coupled with weak revenue collection had created burgeoning deficits, raising concerns about sustainability and the spectre of a debt trap. Allocative efficiency at a macro level had begun to improve even in the Apartheid era, with shifts towards increased social spending (Van der Berg, 2001). However, allocation in sectors such as health and education left much to be desired. Operational efficiency was particularly weak in the homelands and in underserviced Black areas. On the whole, fiscal governance was bedevilled by a lack of transparency and accountability.

South African economy-as a small, open economy-has also had to respond to the uncertainty and volatility of globalisation, and this has curtailed fiscal policy discretion (Abedian, 1998; Calitz, 2000). Globalisation has created pressures to reform fiscal policy institutions and budgetary systems, and also for policy convergence, including deficit reduction, tax reform to broaden the tax base (while lowering marginal rates), and the restructuring of public sector enterprises. Deviant fiscal behaviour, seen as a signal of unsound economic fundamentals, could be penalised by adverse foreign capital flows. Yet the greater integration of capital markets and increased international tax competition have constrained sovereign governments' ability to tax capital flows. It has even been suggested that competitive tax reductions could prevent the financing of significant social welfare spending, though Hines (2006) maintains there is still leverage for increased social expenditures despite greater economic openness.

This paper reviews the policies and outcomes of South Africa's fiscal reform since 1994 and explores the main challenges it has raised. Despite the initial conditions, the South African government has achieved a remarkable turnaround in the fiscal position over the 
decade (Horton, 2005). A large and sustained fiscal adjustment has been supported by the creation of a transparent, constitutionally compliant intergovernmental fiscal relations system, increased quality of fiscal data and improved budget planning and control at all levels of government. The reform of taxation policy, guided by an expert commission, and more efficient tax collection under a new revenue service have produced impressive increases in revenues, permitting widespread tax relief to individuals. Expenditure constraint was exercised initially while the tax system was comprehensively overhauled, promoting a more durable adjustment (Mackenzie et al., 1997). The composition of the fiscal adjustments, containing personnel-related expenditures, subsidies and transfers while actually lowering both company and personal tax rates, has further enhanced the credibility and likely durability of the reform (Alesina and Ardagna, 1998; Alesina et al., 1998). Aggregate budget constraints have been respected for both national and provincial spheres of government. Medium-term expenditure frameworks (MTEFs) have guided expectations, and feasible deficit targets have been consistently met, with the conventional deficit falling from 7.3 to under $1 \%$ of GDP between 1992/3 and 2005/6 (Figure 1). Fiscal consolidation and improved debt management have lowered national debt from 50 to just over 30\% of GDP, promoting greater sustainability of the debt path. The reduced debt service and large cuts in military expenditure have released funds for potential social expenditure and infrastructure investment.

Public finance theory cautions that the longer the response to a debt crisis is deferred, the greater-and more painful—the eventual adjustment required for solvency. The sheer magnitude of the fiscal adjustment in relation to the precarious initial conditions ${ }^{1}$ has signalled the new government's commitment to a credible fiscal policy. The Minister of Finance announced in the Budget Speech in February 2000 that the government had decided to set an inflation target range of $3-6 \%$ for the year 2002. An inflation-targeting framework was successfully adopted by the South African Reserve Bank, and with the support of fiscal policy, targets have been achieved. Monetary policy too is now far more predictable, credible and transparent (Aron and Muellbauer, 2007a,b).

${ }^{1}$ The initial debt to GDP ratio was in fact less than the Maastricht requirement for EU entry. The rapid increase in the debt ratio, the budget deficit and the primary deficit, however, gave cause for alarm. 

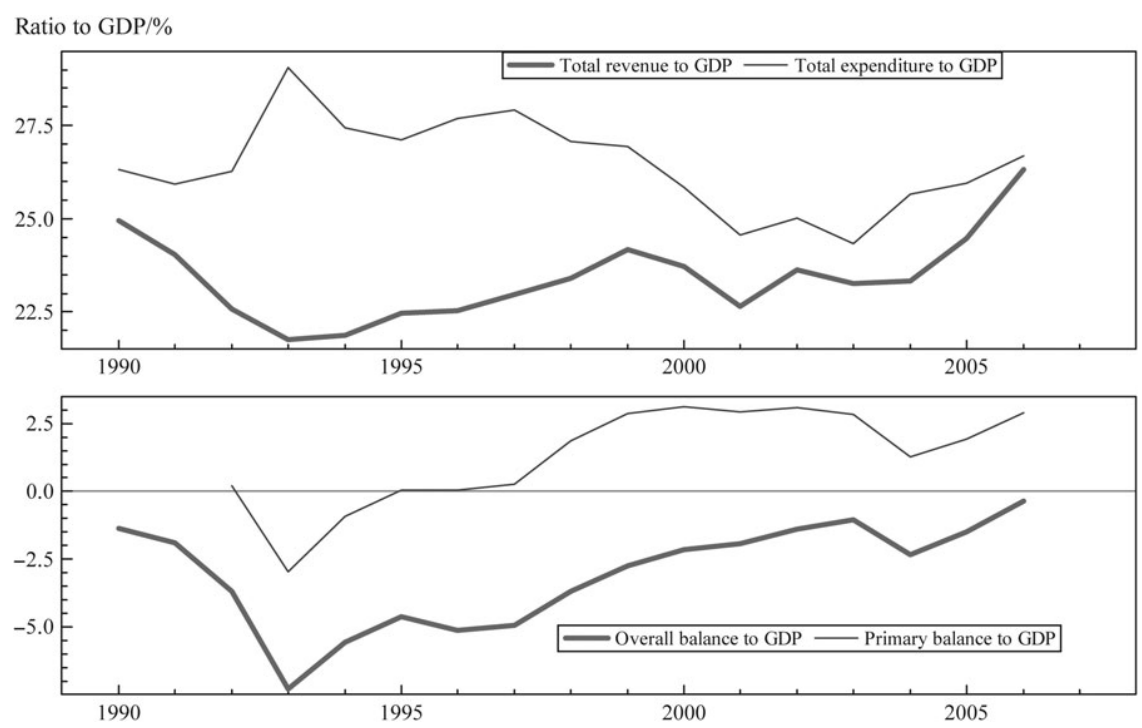

Figure 1: Conventional and Primary Balances as a Percentage of GDP, Fiscal Years from $1989 / 90$

Note: The fiscal year ends in March, and hence, the year 1990 would refer to 1989/90. Source of data: Quarterly Bulletin, South African Reserve Bank, various issues.

Together, the fiscal-monetary policy mix has enhanced macroeconomic stability, thereby reducing uncertainty and improving the investment climate. The fiscal adjustment has not been without its difficulties, however, particularly in microservice delivery in social expenditure areas (such as education, health and housing), while infrastructure spending plans, for instance to ease congestion in South Africa's ports and railways, were instituted ambitiously but far too late.

The outline of the paper is as follows. In Section 2, the improved governance of fiscal policy with its base in constitutional provisions is discussed. The key fiscal reforms since 1994 are summarised in Section 3. The performance of national fiscal policy is examined in Section 4 by means of the trends of the main budget indicators, measures of the cyclically adjusted fiscal stance, a comparison of budget projections and actual outcomes, the management and sustainability of debt and, finally, the contribution of fiscal policy to South Africa's improved macroeconomic stability. Section 5 explores the implications of the vertical fiscal imbalance created by a combination 
of highly centralised revenue-raising powers and increased decentralisation of expenditure responsibility to sub-national governments. Section 6 details the trends in the consolidated government's expenditure priorities, focusing on two areas where service delivery has been poor, housing and education. Section 7 concludes.

\section{Improved Governance of Fiscal Policy}

In South Africa, unlike many other countries, the ideals of good fiscal governance are constitutionally entrenched. The adoption of South Africa's first Constitution in $1996^{2}$ precipitated a paradigm shift in public policy and a restructuring of the public sector. The Constitution required that budget processes of all three spheres of government promote transparency, accountability and effective financial management (Sections 215-217). Legislation was mandated to characterise the form of these budgets when they were tabled. Parliament was granted powers to exercise more effective oversight over budget formulation and implementation (Sections 55 and 77), and even to amend Money Bills. During the Apartheid era, Parliament's role was merely to 'rubber stamp' the budget.

Prior to the 1996 Constitution, the system of fiscal governance in South Africa was highly fragmented, and the wholly inadequate oversight mechanisms resulted in great inefficiencies. There were several distinct budgets in the old dispensation, including those of four provincial administrations and ten homelands (comprising four notionally 'independent states' and six notionally 'selfgoverning' territories). Each homeland had, at least on paper, a legislative assembly, a political executive and an administration of public servants. Hence, these separate public services had to be merged, consolidated and rationalised, while avoiding breakdown in service delivery. The adoption of the Constitution precipitated a complete restructuring into a unitary state with three spheres of government: national, nine provincial governments and 283 local municipalities (down from 784 in the Apartheid era). The Constitution exerted three major influences on the nascent fiscal arrangements of the democratic South Africa: the impetus towards budget and financial management reform; the creation of a fiscally decentralised system of intergovernmental fiscal relations and the provision of justiciable socioeconomic rights.

\footnotetext{
${ }^{2}$ An Interim Constitution was adopted in 1994 and the Final Constitution in 1996.
} 
The Constitution required the establishment of a National Treasury to apply recognised accounting practices, classifications and norms to ensure transparency and expenditure control in each sphere of government, and when financing the deficit through increased public debt (Section 216). Procurement at each level was expected to be 'fair, equitable, transparent, competitive and cost-effective'-though preferential allocation in some cases was allowed for. ${ }^{3}$ The National Assembly of the Parliament was charged with providing mechanisms to enforce oversight for greater accountability (Chapter 4) and oversight over budget formulation and implementation. For greater provincial expenditure control, provision was made for halting for up to four months the transfer of national funds to provinces in breach of legislation, pending Parliamentary approval and a report from the Auditor General.

The emerging intergovernmental fiscal system was influenced by the constitutional requirements for expenditure assignment, revenue-raising powers and intergovernmental grants and borrowing powers. Compared with provincial administrations in the Apartheid state, under the Constitution, the provinces have been assigned greater responsibilities for the delivery of goods and services, either individually or jointly with national government and/or local governments. For instance, with shared responsibility, e.g., in primary and secondary education and health, the national government sets policy but implementation occurs at a sub-national level. However, revenue-raising powers under the Constitution have remained highly centralised. The most productive taxes, such as value-added tax (VAT), personal and corporate income tax, are reserved for the national government. Provincial governments collect very little own revenue (Section 228) and the income raised within the province typically amounts to less than $5 \%$ of the provincial budget. The Fiscal and Financial Commission, an independent body established in terms of the Constitution, ${ }^{4}$ is required to make recommendations to Parliament on equitable allocations to the national, provincial and local governments from nationally collected revenues in line with their expenditure responsibilities and

3 These include policies that restrict tendering for contracts to achieve targets for black empowerment or affirmative action employment.

${ }^{4}$ In the 1996 Constitution, the mandate of the Financial and Fiscal Commission is given in Section 220, while the later Financial and Fiscal Commission Act of 1998 explains the organisation's structure and functions. 
functions. Given that provincial governments and municipalities have limited borrowing powers, ${ }^{5}$ they are highly dependent on their share of nationally collected revenue to finance the implementation of their constitutionally assigned functions.

The separation of policy and financing (at the national level) and implementation (at the provincial level) potentially promotes unfunded mandates and complex coordination problems, and this important issue is discussed in Section 5. Local governments are endowed with more substantial fiscal capacity, being entitled by the Constitution to impose rates on property and surcharges on fees for services provided by or on behalf of the municipality (e.g., for electricity or sewerage). Prior to 1994, many municipalities were in financially precarious positions, were badly managed with dysfunctional systems, and did not engage with the communities they were supposed to serve. However, while the 1996 Constitution sketched a new vision of developmental local government (Chapter 7), and local government has since been in a continual state of transformation, there is little evidence of general improvement.

Most other constitutions confer only civil and political rights upon their citizens. The South African Constitution also confers justiciable socioeconomic rights. The Bill of Rights (Sections 7 through 39) details the obligations of the state to ensure progressive realisation of the right to housing (Section 26), the right to health care, food, water and social security (Section 27) and the right to education (Section 29). Recent jurisprudence has cast some light on the complex issue of the impact of socioeconomic rights on the fiscal system (Ajam and Murray, 2004). Two implications are first, that budgeting and financial management systems would have to be increasingly output-oriented rather than input-driven; secondly, budget allocations and central government grants would need to be closely linked to actual service delivery outputs. It would not be sufficient for the national government to argue that it met its obligations through allocation of sufficient funds for health, education and other forms of service delivery.

${ }^{5}$ Loans may be raised only to finance capital expenditure and not for current expenditure. No national government guarantee is available in respect of subnational claims. 


\section{Fiscal Reforms since 1994}

Fiscal reform initiatives were first articulated through government macroeconomic programmes, the Reconstruction and Development Programme (RDP), launched in January 1994, and the Growth Employment and Redistribution (GEAR) strategy of June 1996. Fiscal prudence, tax reform and increased transparency of administration, a reorientation of spending to social sector and longer term expenditure planning, were hallmarks of both the RDP and the GEAR plans. The fiscal reform strategy has been remarkably consistent over time and can be roughly broken down into three broad areas: budget and financial management reform; the creation of the intergovernmental fiscal system; tax policy and administration reforms.

The budget and financial management reform imperatives of the 1996 Constitution were given substance by the Public Finance Management Act of 1999, initiating the move from an inputoriented expenditure control system towards a more performanceoriented system. The Act formally established the National Treasury, amalgamating the former departments of Finance and State Expenditure. As pointed out by Siebrits and Calitz (2004), the 1999 Act does not prescribe numerical fiscal rules, but emphasises 'regular financial reporting, sound internal expenditure controls, independent audit and supervision of control systems, improved accounting standards and training of financial managers, and greater emphasis on outputs and performance monitoring'. In 2003, the Municipal Finance Management Act extended such budget reforms to local government.

The quality, timeliness and comprehensiveness of fiscal data have much improved since 1994. Fiscal data are regularly published in the Budget Review and in the Intergovernmental Fiscal Reviews. The introduction of the Medium Term Budget Policy Statement (MTBPS) from December 1997 has improved debt and cash management strategies. Published annually, the MTBPS states the government's aggregate revenue and expenditure intentions over the next three years, as well as indicative figures on the division of revenue among provincial governments. Multi-year budgeting, also used in the UK, had its genesis in the 1999 Act, realised through the MTEF in 1998/9, providing three-year rolling budgets for the national and provincial governments in March and 
underlying macroeconomic projections. The intended link between budget reform and the roll-out of the intergovernmental fiscal system was clearly articulated: 'The introduction of three year budgets and their consolidation into resource envelopes is an important step in the evolution of the institutional framework for intergovernmental policy making and budget planning. The intergovernmental forums of the spending departments will, for the first time, have expenditure projections within which to develop and refine the norms and standards for service delivery' (Department of Finance, 1997, p. 5). Since 1999, the budget has been tabled before the start of the financial year. A new budget and reporting format was introduced in 2004, aligned with the International Public Sector Accounting Standards issued by the International Federation of Accountants, and based on a new standard chart of accounts (National Treasury, 2004a, p. vii).

Significant milestones in the evolution of intergovernmental fiscal relations have included the creation of the Budget Council in 1996, an intergovernmental forum presiding over the revenue-sharing process; 6 establishing formula-based revenue sharing, ${ }^{7}$ based on recommendations by the Financial and Fiscal Commission; and promulgation of the Intergovernmental Fiscal Relations Act of 1997 that introduced predictability and transparency into the intergovernmental budget process.

Tax policy and administration reforms have greatly contributed to broadening the tax base and enhancing revenue collection efficiency. Shortly after the 1994 elections, the Katz Commission was appointed to investigate comprehensive administrative and tax reforms, producing eventually nine reports. Foremost from an organisational point of view was the creation of an autonomous revenue service to be known as the South African Revenue Service (SARS), combining the Inland Revenue and Customs and Excise departments. SARS raised audit capability through the introduction of computerised systems, enhaned capacity to investigate and prosecute tax evaders and improved debt recovery procedures.

6 The Budget Council, formalised in the Intergovernmental Fiscal Relations Act of 1997, consists of the National Minister of Finance and his nine provincial counterparts. The Financial and Fiscal Commission attends Budget Council meetings as an observer.

7 The formula-based revenue sharing mechanism initially applied only to provincial governments, but was extended to local governments in 1998/9. 


\section{Tania Ajam and Janine Aron}

At the same time, discriminatory tax legislation was reviewed to further eliminate gender and racial discrimination and to ensure compliance with constitutional provisions on the right to privacy and administrative justice. Some of the tax reforms made between 1994 and 1999 include the granting of tax amnesties, the introduction of tax relief for low- and middle-income taxpayers and the reduction of the number of income tax brackets. Reforms were made to fringe benefit taxation and the taxation of Trusts. Company tax rates and the secondary tax on companies (introduced in 1993/4) were reduced, and there was a significant fall in ad valorem excise tax rates. A tax on retirement funds was introduced in 1996; and in 2000, a capital gains tax was introduced. Tax incentives were introduced for a limited period in the form of a Tax Holiday Scheme and accelerated depreciation allowances. In due course, transfer pricing and thin capitalisation provisions were incorporated in the Income Tax Act. Several double tax treaties with foreign jurisdictions were concluded, and there was also a move from source- to residence-based taxation.

\section{Performance of National Fiscal Policy}

South Africa since 1994 has not adopted legislated constraints on fiscal variables for the national government (i.e., fixed fiscal targets), or numerical rules in the manner of monetary policy (Aron and Muellbauer, 2007b). The rationale behind fiscal rules which pre-commit to certain policies is that they, in principle, trade-off reduced policy-setting freedom and flexibility for greater self-discipline and fiscal credibility. Fiscal rules cannot substitute for authentic government commitment to fiscal discipline, since they can relatively easily be circumvented, ignored or abandoned (Kopits and Symansky, 1998). Siebrits and Calitz (2004) characterise the fiscal regimes used in South Africa as 'target-guided discretion' during 1994-8, and 'transparency-based discretion' thereafter, with an underlying strong commitment to fiscal prudence. They argue that the flexible nature of these regimes has proved beneficial in a volatile external environment of currency crises, political democratization and strong popular pressure for more expansionary policies. Moreover, the limited discretion of fiscal policy has not lost credibility to the Treasury, given its consistent fiscal discipline in practice. 


\subsection{Trends of the Main Budget Indicators}

A feature of the first decade from 1994 is that the authorities maintained a fairly tight overall fiscal position, despite political pressures or constitutional commitments for some degree of expansion, and while operating in a not-always-favourable external environment. At a national level, the considerable fiscal consolidation has been sustained through a mix of expenditure cuts, revenue gains, especially from income taxes, and improved administration. Given that provincial governments have negligible own-revenue sources, the emphasis there was more on expenditure control, especially in the wake of provincial overspending in 1997/8, discussed in Section 5. Consolidation has been supported by the reforms outlined in Section 3. In consequence, there has been a significant reduction in the budget deficit and an improved primary balance, reflecting more sustainable debt management (Figure 1).

Early in 1994, the government had launched the RDP, which emphasised fiscal adjustment. Shortly after the election success of 1994, the government announced a targeted reduction in the budget deficit of $2.5 \%$ of GDP over five years, constant revenues as a share of GDP and cuts in non-interest expenditure. During the early phase of adjustment under the RDP, the fiscal authorities established credibility by meeting deficit targets (Table 1 ). The budget deficit which averaged $4.3 \%$ in the decade to $1992 / 3$, and was $7.3 \%$ of GDP in 1992/3, fell to 5.6\% of GDP in 1993/4, declining further in the subsequent three fiscal years to 5\% of GDP in 1996/7. The primary balance achieved a surplus in 1994/5, which was thereafter sustained. Revenue increased from 21.9 to $23 \%$ of GDP from $1993 / 4$ to $1996 / 7$, facilitated by the establishment of the SARS. Corporate income tax was cut to $35 \%$ in 1995, and the dividend tax reduced by half. Non-interest expenditure was essentially constant, averaging $22.6 \%$ of GDP across these years, with expenditure cuts mainly targeting the wage bill, subsidies and some areas of capital spending. Poor management, however, saw significant provincial expenditure overspending, and subsequently provincial borrowing had to be suspended in 1998/9.

Fiscal reform and consolidation continued with the introduction of the GEAR strategy in June 1996, which aimed for a 3\% of GDP deficit target within 4 years, and a revenue ceiling of $25 \%$ of GDP. The first two budgets after GEAR first cut the wage bill, and 
Table 1: Fiscal Indicators and Cyclically Adjusted Fiscal Estimates

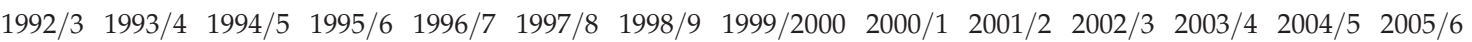

Main budget indicators (in \% of GDP)

\begin{tabular}{|c|c|c|c|c|c|c|c|c|c|c|c|c|c|c|}
\hline Revenue & 21.8 & 21.9 & 22.5 & 22.5 & 23.0 & 23.4 & 24.2 & 23.7 & 22.6 & 23.6 & 23.3 & 23.3 & 24.5 & 26.3 \\
\hline Expenditure & 29.1 & 27.4 & 27.1 & 27.7 & 27.9 & 27.1 & 26.9 & 25.8 & 24.6 & 25.0 & 24.3 & 25.7 & 26.0 & 26.7 \\
\hline $\begin{array}{l}\text { Non-interest } \\
\text { expenditure }\end{array}$ & 24.7 & 22.8 & 22.4 & 22.5 & 22.7 & 21.5 & 21.3 & 20.6 & 19.7 & 20.5 & 20.4 & 22.1 & 22.5 & 23.4 \\
\hline Interest & 4.3 & 4.6 & 4.7 & 5.2 & 5.2 & 5.5 & 5.6 & 5.3 & 4.9 & 4.5 & 3.9 & 3.6 & 3.4 & 3.3 \\
\hline Balance & -7.3 & -5.6 & -4.6 & -5.1 & -5.0 & -3.7 & -2.8 & -2.1 & -1.9 & -1.4 & -1.1 & -2.3 & -1.5 & -0.4 \\
\hline Primary balance & -3.0 & -0.9 & 0.1 & 0.0 & 0.3 & 1.9 & 2.9 & 3.1 & 2.9 & 3.1 & 2.8 & 1.3 & 1.9 & 2.9 \\
\hline Nominal & 381 & 443 & 497 & 564 & 636 & 700 & 753 & 837 & 952 & 1,050 & 1,198 & 1,281 & 1,420 & 1,562 \\
\hline
\end{tabular}

GDP ( $\mathrm{R}$ billions)

Deviations from budget targets (in \% of GDP)

Balance

Primary balance

Revenue

Non-interest

expenditure

Measuring fiscal stance

$\begin{array}{lllllllllllllll}\begin{array}{l}\text { Potential/ } \\ \quad\end{array} \quad 1.030 & 1.017 & 1.002 & 1.000 & 0.981 & 0.988 & 1.009 & 1.005 & 0.997 & 1.004 & 1.000 & 1.010 & 0.999 & 0.994 \\ \text { Fiscal stance } & 5.3 & 3.5 & 2.8 & 2.9 & 3.1 & 1.3 & -0.1 & -0.3 & 0.1 & -0.2 & 0.1 & 1.5 & 1.0 & 0.2 \\ \text { Revenue } & 0.9 & 0.8 & 0.2 & 0.1 & -0.3 & -0.8 & -1.5 & -1.1 & 0.0 & -1.0 & -0.6 & -0.7 & -1.8 & -3.7\end{array}$

$\begin{array}{llllllll}0.4 & 0.9 & 0.5 & 1.0 & 0.8 & 0.0 & 1.5 & 2.7 \\ 0.5 & 0.6 & 0.5 & 0.9 & 0.8 & -0.4 & 1.4 & 2.6 \\ 0.7 & 0.8 & 0.5 & 1.4 & 1.1 & -0.4 & 1.4 & 2.6 \\ 0.2 & 0.2 & 0.1 & 0.5 & 0.4 & 0.0 & 0.1 & 0.1\end{array}$

stance 


\begin{tabular}{|c|c|c|c|c|c|c|c|c|c|c|c|c|c|c|}
\hline $\begin{array}{l}\text { Non-interest } \\
\text { expenditure } \\
\text { stance }\end{array}$ & 4.4 & 2.8 & 2.7 & 2.8 & 3.4 & 2.1 & 1.4 & 0.8 & 0.1 & 0.7 & 0.7 & 2.2 & 2.8 & 3.8 \\
\hline $\begin{array}{l}\text { Fiscal } \\
\text { impulse }\end{array}$ & & -1.8 & -0.7 & 0.1 & 0.2 & -1.8 & -1.4 & -0.2 & 0.4 & -0.3 & 0.4 & 1.4 & -0.5 & -0.9 \\
\hline $\begin{array}{l}\text { Revenue } \\
\text { impulse }\end{array}$ & & -0.1 & -0.6 & -0.1 & -0.4 & -0.4 & -0.8 & 0.5 & 1.1 & -1.0 & 0.3 & -0.1 & -1.1 & -1.9 \\
\hline $\begin{array}{l}\text { Non-interest } \\
\text { expenditure } \\
\text { impulse }\end{array}$ & & -1.7 & -0.1 & 0.1 & 0.6 & -1.3 & -0.7 & -0.6 & -0.7 & 0.7 & 0.0 & 1.4 & 0.7 & 1.0 \\
\hline
\end{tabular}

Source: Calculations using data from the Quarterly Bulletin, South African Reserve Bank, various issues. 
a year later, limited civil service wage rises and strengthened management in the provincial and municipal governments. Provincial performance improved and registered a surplus in 1998/9, and together with revenue gains under SARS, the deficit target was easily met in 1998/9. The deficit fell to $3.7 \%$ in $1997 / 8$ and then to $2.8 \%$ in $1998 / 9$, with the primary surplus reaching $3.1 \%$ of GDP in 1999/2000 (Table 1). Revenue had climbed to $24.2 \%$ of GDP by $1998 / 9$, while non-interest expenditure fell to $21.3 \%$ of GDP. The MTEF was also introduced in 1998/9, allowing multiyear budgeting.

The institutional reforms governing revenue collection and expenditure management bore fruit in the following fiscal years from 1999/2000, the latter strengthened by the passing of the Public Finance Management Act in 1999 (Section 2). By 2002/3, the deficit had fallen to its lowest level since the start of reforms, of $1.1 \%$ of GDP. Debt management improvements and lower interest rates that were redeployed to social and some capital expenditure brought sustained savings on debt service, bringing the primary surplus to $1.4 \%$ of GDP by $2003 / 4$. The ceiling for revenue to GDP of $25 \%$ continued to be observed until 2005/6. Expenditure cuts continued to focus on the wage bill, with cuts in civil service employment phased in from 1998 on. The corporate income tax rate was lowered further to $30 \%$ and a capital gains tax was introduced. Worldwide income came under the personal income taxation net, but tax rates were lowered and thresholds adjusted. In the 2003/4 budget and the following two budgets, a larger deficit of $3.1 \%$ was projected, with plans for increased social sector spending (including the provision of HIV/AIDS drugs) and capital spending. In the event, the actual deficits were far lower, at $2.3 \%$, $1.5 \%$ and only $0.4 \%$ of GDP, respectively, partly due to poor capacity in provincial administrations resulting in unspent funds. The MTEF projections to 2008/9 continue to signal the government's intention to maintain a more expansionary stance.

The tax reforms over the last decade have markedly improved the effectiveness of tax collection and revenue sources have diversified (Table 2). The broadening of the tax base has permitted considerable tax relief since 1995, of which $85 \%$ comprised personal income tax relief. The declining importance of taxes on international trade and transactions as a source of revenue reflects the government's trade liberalisation policies. VAT accounted for roughly a quarter 
Table 2: The Changing Composition of Revenue Sources

\begin{tabular}{|c|c|c|c|c|c|c|c|c|c|}
\hline & $\begin{array}{l}\text { Persons and } \\
\text { individuals }\end{array}$ & Companies & STC & $\begin{array}{l}\text { Tax on } \\
\text { retirement } \\
\text { funds }{ }^{b}\end{array}$ & $\begin{array}{l}\text { Taxes on } \\
\text { Property }\end{array}$ & $\mathrm{VAT}^{\mathrm{d}}$ & $\begin{array}{l}\text { Taxes on } \\
\text { international } \\
\text { trade and } \\
\text { transactions }\end{array}$ & $\begin{array}{l}\text { Fuel } \\
\text { levy }^{f}\end{array}$ & $\begin{array}{l}\text { Other } \\
\text { taxes }^{g}\end{array}$ \\
\hline \multicolumn{10}{|c|}{ Average \% contribution of revenue sources to total main budget tax revenue/\% } \\
\hline $1986 / 87-1993 / 94^{\mathrm{a}}$ & 34.3 & 19.7 & 0.1 & 0.0 & 1.6 & 25.1 & 5.5 & 6.5 & 7.2 \\
\hline $1993 / 94-1999 / 00^{a}$ & 41.0 & 12.1 & 1.1 & 1.5 & 1.7 & 24.7 & 7.2 & 4.1 & 6.6 \\
\hline 1999/00-2005/06 & 33.7 & 18.4 & 2.3 & 1.9 & 2.1 & 25.9 & 5.3 & 3.6 & 6.7 \\
\hline $2005 / 06-2008 / 09^{\mathrm{h}}$ & 29.7 & 20.8 & 3.0 & 0.5 & 2.2 & 28.4 & 4.3 & 5.1 & 6.1 \\
\hline \multicolumn{10}{|c|}{ Average annual nominal growth rates of revenue source/\% } \\
\hline $1986 / 87-1993 / 94^{\mathrm{a}}$ & 20.1 & 4.1 & - & - & 14.5 & 15.9 & 46.9 & 12.7 & 14.8 \\
\hline $1993 / 94-1999 / 00^{a}$ & 14.7 & 10.5 & 23.8 & 27.6 & 16.8 & 11.3 & 10.5 & 4.4 & 9.9 \\
\hline $1999 / 00-2005 / 06$ & 6.6 & 26.2 & 24.7 & -2.8 & 19.6 & 15.5 & 2.6 & 18.7 & 14.1 \\
\hline $2005 / 06-2008 / 09^{\mathrm{h}}$ & 10.4 & 11.0 & 11.2 & -14.6 & 4.9 & 10.9 & 15.3 & 13.1 & 3.1 \\
\hline
\end{tabular}




$\begin{array}{lllll}\begin{array}{l}\text { Persons and } \\ \text { individuals }\end{array} & \text { Companies STC } & \begin{array}{l}\text { Tax on } \\ \text { retirement } \\ \text { funds }^{b}\end{array} & \begin{array}{l}\text { Taxes on } \\ \text { Property }^{c}\end{array} & \text { VAT }^{\mathrm{d}} \begin{array}{l}\text { Taxes on } \\ \text { international } \\ \text { trade and } \\ \text { transactions }\end{array}\end{array}$

Average annual real growth rates of revenue source/\%

$\begin{array}{llrrrrrrrr}1999 / 00-2005 / 06 & 0.13 & 18.6 & 17.2 & -8.7 & 12.3 & 8.6 & -3.6 & 11.5 & 7.3 \\ 2005 / 06-2008 / 09^{\mathrm{h}} & 5.6 & 6.2 & 6.39 & -18.3 & 0.37 & 6.1 & 10.3 & 8.2 & -1.4\end{array}$

Source: Calculations based on National Treasury (2006) and other Budget Reviews. Real annual growth rates obtained using CPIX deflator $(2000=100)$. CPIX projections for the MTEF period based on National Treasury $(2005$, p. 12).

aFigures prior to 1995/6 include collections by the former TBVC states and self-governing territories.

${ }^{\mathrm{b}}$ Average annual growth rates for retirement funds tax introduced in 1996/7 are from 1996/7-1990/2000.

${ }^{\mathrm{c}}$ Taxes on property includes donation tax, estate duty, marketable securities tax and transfer duties.

${ }^{\mathrm{d}}$ Including sales duty, replaced by general sales tax in July 1978 and VAT in September 1991.

${ }^{\mathrm{e}}$ Including customs duties, import surcharges, diamond export duties, miscellaneous customs and excise income, as well as ordinary levy collections.

fIncluding the former fuel levy directed to Regional Services Councils and the levy allocated to the National Road Fund for the period $1983 / 4$ to $1986 / 7$.

${ }^{\mathrm{g}}$ Including various levies, mining leases and ownership, cinematographic tax and other special levies, the skills development levy, specific and ad valorem taxes and stamp duties and fees.

${ }^{h}$ MTEF period. 
of total gross tax revenues from 1986/7 to 2004/5. Personal income tax has declined from an average of 41 to $34 \%$ of total gross tax revenue, between the periods 1993/4 to 1999/2000 and 1999/2000 to $2005 / 6$. Concomitantly, a greater share was taken by company taxation, and two relatively new taxes, the secondary tax on companies (STC, introduced in 1993/4) and the tax on retirement funds. The last decade was also characterised by increases in the number of user charges (e.g., toll road fees, hospital fees and other direct payments for benefits received). Calitz and Siebrits (2003) have noted the redistributive thrust of these charges.

\subsection{Cyclically Adjusted Fiscal Measures}

To estimate the fiscal stance purely as a result of discretionary fiscal policy, a correction can be made for cyclical economic factors that may have affected revenue and expenditure. For instance, in periods during which output exceeds potential or trend output (i.e., when the output gap is positive), there will be an enhanced tax taken from the increased output and possibly reduced expenditures on social benefits due to greater demand in the economy, resulting in an overall contraction of the budget deficit. A simple way to adjust fiscal estimates cyclically is to employ a measure of the output gap to adjust revenue and expenditure values relative to GDP to the amounts needed to maintain revenue and expenditure at the level of a neutral or base year, that is, a year when potential and actual output approximately coincided. Subtracting these neutral levels of revenue and expenditure from actual levels of revenue and expenditure gives the revenue stance and expenditure stance, from which the fiscal stance can be calculated.

We update the exercise of Horton (2005), estimating potential output for South Africa using a Hodrick Prescott filter, but choosing the fiscal year 2000/1 as the reference year when the output gap was close to zero. ${ }^{8}$ The fiscal stance, shown in Table 1 , is calculated as the difference between the revenue stance and the (non-interest)

${ }^{8}$ Horton's choice of the base year 1998/9, though the output gap was close to zero, is perhaps less plausible than 2000/1, given the very high interest rates experienced that year following an exchange rate crisis, and that induced the lowest real annual growth rate in a decade. In 2000/1, the output gap was also close to zero, but more normal macroeconomic conditions prevailed. Further, the new data from the benchmarking and rebasing of the National Accounts (December 2004) and revised budgetary data are used here. 

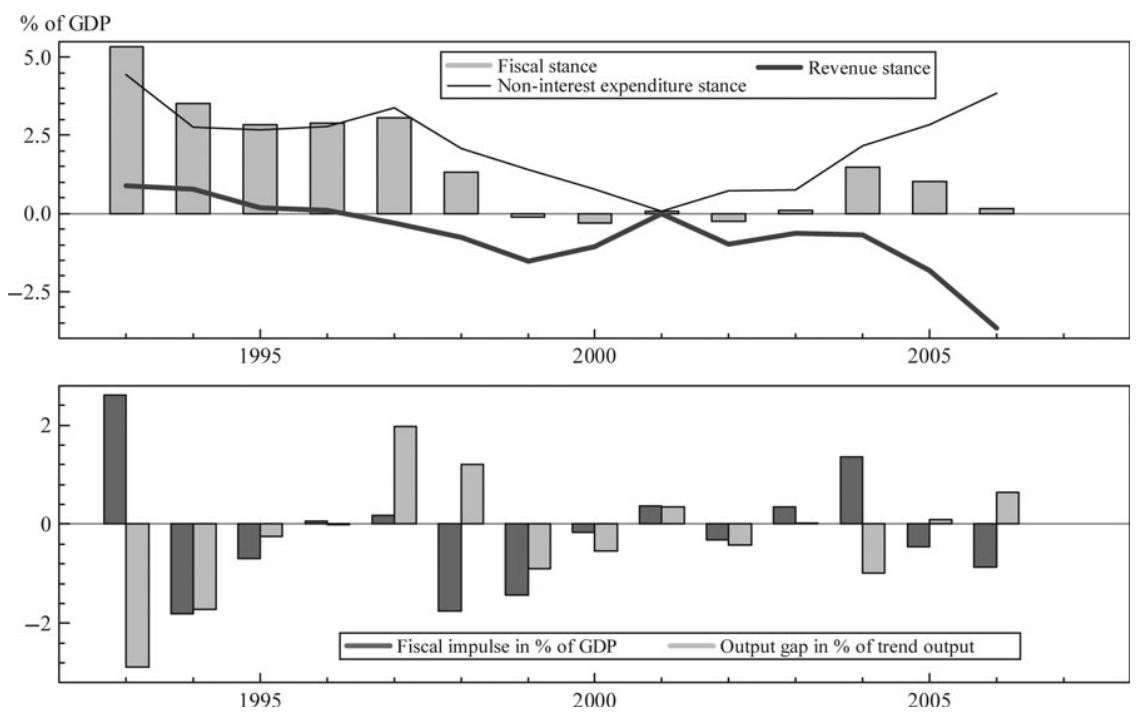

Figure 2: Fiscal Impulse and the Output Gap, Fiscal Years from 1992/3

Note: The fiscal year ends in March, and hence, the year 1993 would refer to 1992/3. Source: Calculations using data from the Quarterly Bulletin, South African Reserve Bank, various issues.

For details of calculations, see Table 1.

expenditure stance, or the primary balance relative to its neutral value. ${ }^{9}$ The annual change in the fiscal stance is termed the fiscal impulse, and it reveals whether the policy is tightened (negative impulse) or loosened (positive impulse). The revenue or expenditure impulses can reveal the sources of the policy change. Table 1 and Figure 2 suggest that discretionary policy was tightened from $1992 / 3$, with the fiscal stance rather positive at the outset, but falling to zero from a combination of expenditure cuts and revenue gains by 1998/9. Sharp expenditure cuts are shown by the negative expenditure impulse for 1993/4 and 1997/8, when the fiscal impulse was strongly negative, and moderate cuts ensued in the following three years. In 1998/9, the impact of the

9 The assumption for the calculation of neutral values is that neutral revenue grows at the rate of GDP, while neutral non-interest expenditure grows at the rate of trend GDP (as in Horton, 2005). One would expect revenue to fluctuate with GDP, but expenditure to move more smoothly, since a social benefits system is not developed in South Africa (social expenditures are planned in advance for means-tested or age-threshold groups). 
establishment of SARS and associated reforms is apparent in a supportive negative revenue impulse, and significant negative revenue impulses are also seen in 2001/2, 2004/5 and 2005/6. The rise in budgeted social and investment spending after 2001/2 loosens the fiscal stance, despite the revenue gains.

Comparing the output gap with the fiscal impulse (Figure 2) suggests that before about 2002/3, the policy had been largely pro-cyclical (with the exception of 1997/8), but has become more counter-cyclical in the most recent years. For instance, when the actual output was less than the potential output (the output gap was negative), before 2000/1, the fiscal impulse was also negative. Thus, when there was excess capacity in the economy, fiscal policy continued to be consolidated in the early years, but it relaxed with excess capacity in $2003 / 4$. Three years have experienced a fiscal stimulus since 1999/2000.

An alternative approach to distinguish discretionary and cyclical fiscal policy, by the estimation of structural balance indicators, has been executed by Horton (2005) and Swanepoel and Schoeman (2003) for different periods and assumptions. Horton's results confirm the above findings of discretionary tightening to 1999/2000 (with the exception of 1996/7), and loosening thereafter, especially in 2003/4. Swanepoel and Schoeman (2003) concur that fiscal discretionary policies were frequently procyclical, including fiscal consolidation during a period of slower economic growth in 1993-9.

The degree of fiscal discipline is remarkable in the light of theories of public expenditure, such as the Meltzer-Richard hypothesis, which posits that in countries with highly unequal income distribution, the extension of voting rights to lower income groups is likely to increase the growth of redistributive public expenditure (Meltzer and Richard, 1981). Black et al. (2005, p. 97-98) point to two factors that help explain the restraint: some redistribution had already occurred prior to 1994; and post-1994 reforms achieved a re-allocation of spending without significant increases in government's overall expenditure share. The signalling effect for global capital flows alluded to earlier may also have contributed to the fiscal restraint.

\subsection{Budget Projections and Actual Outcomes}

The deviations of actual revenue, non-interest expenditure and balance measures from budget targets, as a percentage of GDP, 


\section{Tania Ajam and Janine Aron}

are also shown in Table 1. Actual expenditures have usually been close to planned limits or, in some cases, have undershot limits. In 2003/4, despite intentions to increase spending, actual expenditure was below budgeted, indicating lack of spending capacity. In contrast, even when revenue projections were revised upwards in the budgets, these were outstripped by actual collections. The windfall tax revenue gain in 2001/2 translated directly into personal income tax relief the following year. In 2003/4, tax collections fell below budgeted estimates, attributable to lower company profits and customs receipts in an environment of muted economic growth. In 2004/5 and especially in 2005/6, actual revenues again exceeded estimates, indicating that diminishing returns to tax reform had not yet set in. The result has been stronger balance and primary balance outturns than budgeted, which in recent years have amounted to more than $1 \%$ of GDP. Factors causing deviations include fluctuations in the business cycle and periods of both overspending and underspending by provincial governments, but mainly over-conservative revenue projections, particularly of corporate income tax after 1999.

\subsection{Debt Management and Sustainability}

The net borrowing requirement of the main budget is obtained by subtracting extraordinary transfers from the deficit on the main budget and adding extraordinary receipts. ${ }^{10}$ The net borrowing requirement is financed through changes in domestic and foreign loan liabilities and changes in cash and other balances. The consolidation of the fiscal position has helped reduce domestic debt from 50 to 34\% of GDP between 1998/9 and 2005/6 (Figure 3), and debt service has correspondingly fallen from 6 to just above $3 \%$ of GDP. Foreign debt remains a small proportion of overall debt, at just above $4 \%$ of GDP in $2005 / 6$, up from about $1 \%$ of GDP in $1993 / 4$. Foreign debt rose to nearly $8 \%$ of GDP in $2001 / 2$, reflecting increased borrowing (at longer maturities) and the effects of the rand depreciation. Debt management has focused on extending the maturities of foreign debt and domestic debt, consolidating debt instruments and introducing inflation-indexed bonds.

${ }^{10}$ Extraordinary transfers include premiums received on destination bonds in switch auctions. Extraordinary receipts include proceeds of sale of state assets and strategic supplies, as well as 'book profit' on domestic government bond buybacks and source bonds issued in source auctions. 


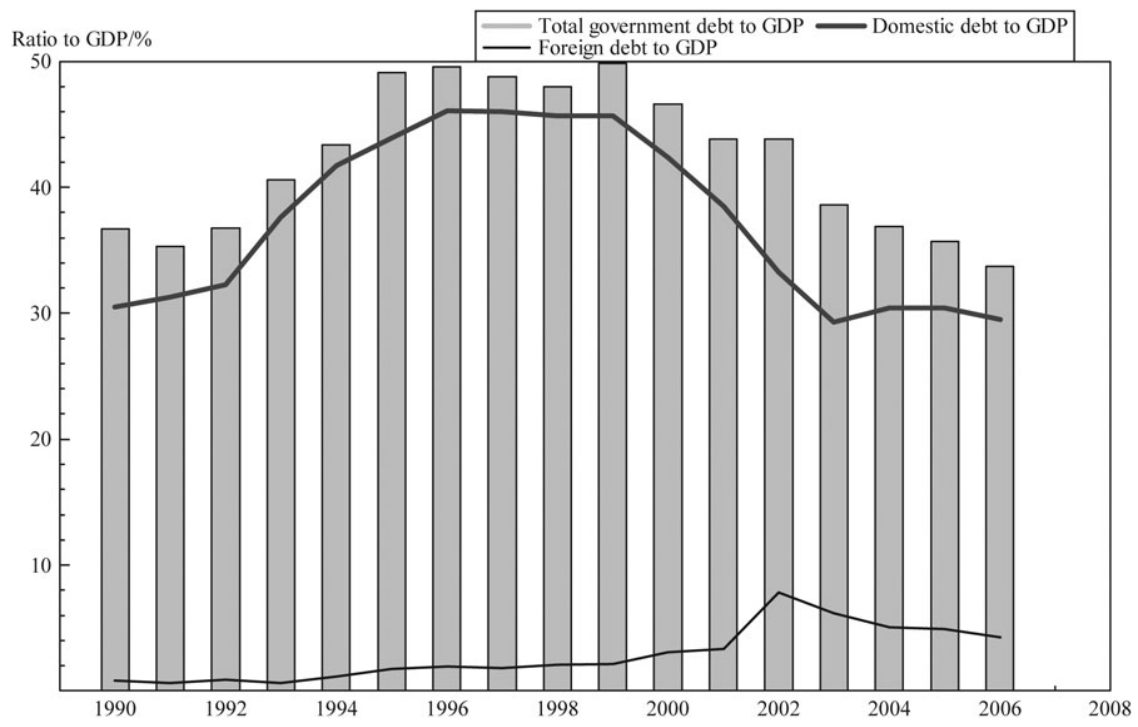

Figure 3: Debt Indicators, Fiscal Years from 1989/90.

Note: The fiscal year ends in March, and hence, the year 1990 would refer to 1989/90. Source of data: Quarterly Bulletin, South African Reserve Bank, various issues.

Increased diversification and an improved term structure of debt have contributed to reduced fiscal risk.

Horton (2005), under a range of cautious assumptions, ${ }^{11}$ projects debt forward from 2004 and examines the dynamics under a variety of short-term shocks. The shocks include a fall in growth, substantial real depreciation of the exchange rate, increase in the debt stock and a worsening of the primary balance. He finds the projected debt is moderate and sustainable over the next decade.

\subsection{The Contribution of Fiscal Policy to South Africa's Improved Macroeconomic Stability}

South Africa's growth performance has improved in the last decade relative to the preceding decade: real economic growth rate averaged 3.1\% (1.1\% per capita) during 1995-2004 versus

11 The assumptions include revenue remaining below 25\% of GDP, extra expenditure of $0.1-0.2 \%$ of GDP for health (HIV/AIDS treatment), but other noninterest expenditure to remain constant, growth at around 3\% per annum, a constant real effective exchange rate and interest rates declining slightly in the medium term. 


\section{Tania Ajam and Janine Aron}

$0.8 \%(-1.3 \%$ per capita) during 1985-94. However, the decade average remains low by world and South Africa's own historical standards (Du Plessis and Smit, 2007). The combination of tight fiscal and monetary policies may have contributed to depressing growth rates, particularly during 1998 (when nominal interest rates rose to more than $25 \%$ ) and 1999. However, the finance minister's decision for the central bank to adopt inflation targeting from early 2000 under a new governor has greatly improved the transparency, credibility and predictability of monetary policy (Aron and Muellbauer, 2007a). With better management of interest rates under inflation targeting and reduced volatility, perceived currency and sovereign credit risks have declined, tax-adjusted real interest rates are far lower, and consumer price inflation has fallen from double-digit figures in the 1990s to well within the $3-6 \%$ target range from late 2003 . The fiscal consolidation and improved transparency and predictability of fiscal policy have supported monetary policy: the improved coordination of fiscal and monetary policy is a further strength of post-Apartheid reform. Fiscal constraint has also helped to bolster national savings, as household saving has fallen sharply over the decade. A case could be made that growth could have been more severely compromised had the inherited fiscal threat not been neutralised first, under the difficult conditions of currency volatility and low investor confidence.

The fiscal-monetary policy mix has created an environment of macroeconomic stability conducive to future growth (Aron and Muellbauer, 2005). Empirical evidence suggests that investment in South Africa is substantially driven by uncertainty. This is true for private sector physical capital augmentation, for portfolio capital flows and for foreign direct investment (Fielding 2000; Fedderke and Liu, 2002; Fedderke, 2004; Fedderke and Romm, 2005). With the improvement of the investment climate through greater systemic stability of South Africa and improved policy credibility and transparency, lower business costs have promoted investment in all three dimensions. However, while a more efficient tax system may have promoted private sector participation in the economy, with low inflation, there has been a further shift in effective taxation from the personal to the corporate sector, ${ }^{12}$ and

12 Corporations can deduct interest on debt from taxable profits, while households cannot deduct such interest from taxable income, and interest rates have fallen with lower inflation. 
effective corporate tax rates remain high by the standards of comparable emerging market countries (Aron and Muellbauer, 2005).

Unfortunately, the public capital constraint is only belatedly receiving extensive policy attention (e.g., significant expansions were planned in the 2005 budget). In line with international evidence, infrastructure in South Africa has been found to influence growth (Perkins et al., 2005), with electricity capacity having the greatest and most robust impact. Yet there has been a long-term decline in infrastructure investment and capital stock, with real investment per capita falling by 72\% from 1976 to 2002 (Bogetić and Fedderke, 2006), which should have been addressed earlier. In the case of low-quality education and training, another important long-term constraint on growth, the discussion in Section 6 suggests that fiscal allocation is only part of the solution to these ills. The issue is not the quantum of education expenditure (this is South Africa's single largest non-interest government expenditure item and it spends much more than its developing country counterparts), but effectiveness and efficiency.

\section{Fiscal Decentralisation}

The highly centralised nature of revenue-raising powers in South Africa, with increased decentralisation of expenditure responsibility, has created a vertical fiscal imbalance. Provincial governments face significant expenditure mandates, but have restricted own financial resources. Provincial governments are highly dependent on the 'equitable share' grant, regulated by Section 214 of the Constitution, to finance the implementation of their constitutionally assigned functions. After deducting interest obligations and other statutory payments from total tax collected by SARS and other revenues, the balance is 'equitably' split up among the three spheres of government. The provinces also receive conditional grants which they have to earmark for pre-specified purposes, such as health, infrastructure, housing and social development. Equitable share allocations and conditional grants comprised roughly $96 \%$ of all provincial revenue in $2003 / 4$. The share of overall nationally collected revenue for the national government fell from more than $42 \%$ in $1989 / 99$ to around $37 \%$ by $2005 / 6$ for the national government, while rising for provincial and especially local government. 
This increase in revenue for sub-national governments helped to finance their increased expenditure responsibilities.

The fiscal federalism literature suggests that such a mismatch between revenue and expenditure powers could potentially weaken accountability at the margin and lead to soft budget constraints at sub-national levels, possibly even creating disincentives for raising resources at the national level (Shah, 1994). Conventionally, it is suggested that the assignment of spending responsibility should precede the division of tax powers. However, Rao and Singh (1999) suggest that the choice between assigning tax powers and providing transfers to sub-national governments to finance their services depends upon the trade-off between the additional efficiency loss due to sub-national taxation and efficiency gains from cost-efficient spending by them (plus considerations of regional equity). In Australia, Breton (1996) and Groenewegen (1979) argue that, vertical fiscal imbalances in fiscal federal arrangements reflect rational economic motives, as the 'high coordination costs' of administering income tax and some other taxation have required 'high concentration' of powers. Similarly, Momoniat (2002), one of the architects of the South African fiscal system, suggests that the design, though departing from the conventional prescripts of fiscal federalism theory, has been advantageous. He argues for the maximisation of the revenue potential of existing revenue sources, and phasing in devolved additional taxation powers only after effective expenditure controls and efficient revenue collection procedures are firmly in place. The risk of moral hazard could then be contained with a strict no-bail-out approach by the government, backed by a policy of not guaranteeing sub-national loans or deficits.

Provincial governments, in aggregate, were substantially in deficit from 1996/7, which reverted to a surplus from 1998/9 to 2001/2 (Figure 4). That all provincial governments were affected to a greater or lesser extent has suggested systemic problems in the intergovernmental system. Underbudgeting has been cited as the main reason for these deficits rather than overspending (Department of Finance, 1998, p. 13). The lion's share of provincial budgets is devoted to personnel-related expenditures, linked to the delivery of labour intensive health and education services, while roughly a third is on social development. This introduces rigidity to provincial budgets, since social security benefits are set nationally and provinces have very little control over salaries. In 1996/7, the 


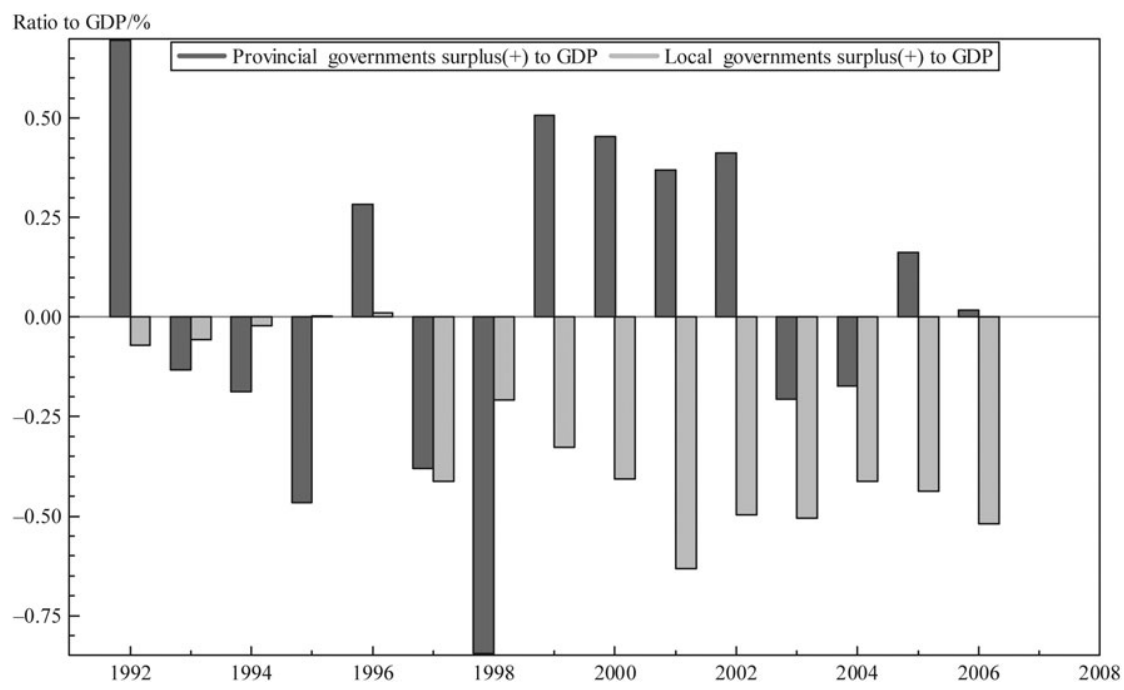

Figure 4: Provincial and Local Governments' Deficits and Surpluses, Fiscal Years from $1991 / 2$

Note: The fiscal year ends in March, and hence, the year 1992 would refer to 1991/2 Source of data: Quarterly Bulletin, South African Reserve Bank, various issues.

employment of teachers and health personnel was expanded with improved remuneration, as provincial governments started addressing backlogs in these two areas. Health and education costs rose by 26 and 31\%, respectively, from 1995/6 to 1996/7. An inherited incremental budgeting system, based on the previous year's budgeted figures rather than actual figures, resulted in the budgeted personnel ${ }^{13}$ increases falling well below increases in actual expenditure. The situation was compounded by bad financial management systems and lack of effective internal controls. Budget 'gaming' may also have occurred, where provinces deliberately underbudgeted in the hope of receiving a bail-out from the national government.

The national government eventually did intervene in terms of Section $100^{14}$ of the Constitution, in response to this overspending

${ }^{13}$ Not all civil servants from the ex-homelands had unique identity numbers or were on the government payroll system. In addition, 'ghost' workers were rife.

14 This allows the national government to intervene when a provincial government fails to meet an executive obligation. The Eastern Cape government had failed to make welfare payments, triggering constitutional court challenges, and failed to pay creditors. 
episode. The two most affected provinces (the Eastern Cape and KwaZulu-Natal) were bailed out and further funds were distributed to all provincial governments. There were fears that this would lead to a softening of provincial governments' budget constraints; however, the bail-outs were conditional on improvements in financial management and an undertaking by the affected provinces to run budget surpluses in 1998/9 to repay their debt. This took considerable political will, given the fact that KwaZuluNatal and the Eastern Cape are two of the poorest provinces in South Africa with a significant social backlog. A further payment was allocated to provincial governments in the 1998/9 adjustments budget, conditional on their agreement to implement debt repayment schedules.

The surpluses in 1999/2000 and in 2000/1 were not solely a response to debt repayment obligations. They also reflected an inability to spend budget allocations, with the binding constraint not being purely financial, but rather one of management capacity, especially in relation to capital projects. The fiscal constriction coupled with an inability to spend effectively impacted on service delivery in the Eastern Cape and KwaZulu-Natal between 1995/6 and 2000/1. Significantly lower growth rates resulted for social development expenditure and education in these two provinces, by comparison with other historically disadvantaged provinces, such as Limpopo, Mpumalanga and the North West. ${ }^{15}$

A conditional grant for spending on social grants arrears in the $2002 / 3$ financial year was transferred at the end of the 2001/2 fiscal year. When this is netted out, the $2001 / 2$ surplus declines significantly. In 2002/3 and 2003/4, provincial governments again ran deficits (Figure 4). The 2002/3 deficits were planned and budgeted for, funded from the cash balances available to provincial governments after debt payments (National Treasury, 2003, p. 15). The deficits were also driven by increases in transfers, in particular, the

15 The horizontal division of the total provincial share to the individual provinces (and of the total local government share to individual municipalities) is effected by means of a formula. The formula is updated to reflect new census data, typically phased in over time in order to avoid undermining the predictability of provincial budgets. This primarily demographically driven formula is highly redistributive. Between 1998/9 and 2003/4, of the nine new provinces, the Northern Cape's share has remained fairly constant, the Western Cape and Eastern Cape shares have declined and the shares of the more populous Gauteng, KwaZulu-Natal and Limpopo have increased. 
child support grant. Of the combined provincial deficit in 2003/4, just over half was due to overexpenditure on social security grants, which had grown at an annualised rate of more than $40 \%$ (National Treasury, 2004a, p. 158). The following two fiscal years again saw provincial surpluses.

It is interesting to reflect on how the costs and benefits of consolidation were apportioned between the national and provincial levels of government. The benefits would appear to have accrued mainly at the national level (i.e., greater aggregate fiscal discipline leading to lower deficits and hence better country risk ratings and lower costs of borrowing). Provincial governments also gained from fiscal consolidation to the extent that decreasing interest payments freed up more discretionary resources that could be diverted to the social spending that comprises most of provincial expenditure. In terms of expenditure control and service delivery forgone, the bulk of the costs would probably have accrued to the provinces. Nevertheless, it must be borne in mind that provincial governments probably did not, and indeed still do not, have the capacity to spend intergovernmental grants effectively. So even if more funds were available, this may not have resulted in better quality infrastructure in previously disadvantaged areas or the recruitment of more skilled personnel to those areas.

What implications do these outcomes hold for the political economy of South Africa and the balance of power between the provincial and federal levels of government? The bottom line is that while South Africa has done exceptionally well in stabilising the macroeconomy, the microeconomic objectives still require concerted focus. The creation of provincial governments was not driven by economic motives, but primarily political motives. There is now concern about the future of provincial governments, especially those that are not delivering. One proposal has been to amalgamate provincial governments (e.g., Northern Cape and Western Cape; or Mpumalanga, Gauteng and Limpopo back into the old 'Transvaal'). An alternative suggestion is to disestablish provincial legislatures, turning provincial governments back into administrative arms only. Unfortunately, the creation of the nine provincial legislatures initiated political rents for governing party-elected members who could not get onto the national party list, and resistance could be expected from this vested interest group. On the other hand, political pressure in response to poor service delivery is mounting. This 
may encourage the national government to 're-centralise' policy influence over provincial functions by reducing the fiscal autonomy to provincial governments in the grant system. This could be done by making large unconditional grants (like the equitable share grants) conditional.

\section{Consolidated Government's Expenditure Priorities}

South Africa inherited a highly unequal wealth and income distribution and a legacy of decades-long discriminatory provision in health, education and infrastructure across population groups. The reorientation of spending away from defence and subsidies, and a reduced debt burden through improved debt management, has freed spending for social purposes, under the constraint of the overall fiscal targets. Consolidated national and provincial figures give an indication of the changing priorities accorded to expenditure categories. 'Social services' jointly consume the bulk of non-interest-consolidated national and provincial expenditure, averaging just below $60 \%$ of total expenditure (Table 3). Education expenditure at $22 \%$ is the single largest expenditure item of this category, followed by social development and health. Social welfare expenditure, which includes means-tested child support grants, disability grants and universal old-age grants, is expected to increase to $18.5 \%$ of non-interest expenditure over the MTEF period, with health and education falling in importance to 11.8 and $20.7 \%$, respectively (Table 3 ).

We focus in detail on two categories, education and housing, to illustrate some of the achievements and constraints in social spending. Table 3 shows that in annual growth terms, real housing expenditure actually declined by 31\% between 1997/8 and 1999/2000 and grew by only $6.8 \%$ between $1999 / 2000$ and 2005/6 (although expected to increase to $11.3 \%$ over the MTEF period). The decline may reflect capacity constraints to spend effectively, owing to factors such as non-availability of suitable land, inadequate coordination with municipalities in respect of the delivery of complementary basic services (such as water and electricity), uncoordinated policies and constraints on financing (National Treasury, 2003, p. 174). In $2002 / 3$, for example, only $76 \%$ of budgeted Housing Subsidy Grants were spent. While the North West and the Western Cape provinces spent all available funds, the Eastern 
Table 3: Consolidated National, Provincial and Security Fund (Non-interest) Expenditure by Functional Area

\begin{tabular}{|c|c|c|c|c|c|c|c|c|c|c|c|c|c|c|c|}
\hline & \multicolumn{12}{|c|}{ Percentage of consolidated national and provincial expenditure } & \multicolumn{3}{|c|}{ Real annual growth $/ \%$} \\
\hline & $\begin{array}{l}1997 / \\
8\end{array}$ & $\begin{array}{l}1998 / \\
9\end{array}$ & $\begin{array}{l}1999 / \\
2000\end{array}$ & $\begin{array}{l}2000 / \\
1\end{array}$ & $\begin{array}{l}2002 / \\
3\end{array}$ & $\begin{array}{l}2002 / \\
3\end{array}$ & $\begin{array}{l}2003 / \\
4\end{array}$ & $\begin{array}{l}2004 / \\
5\end{array}$ & $\begin{array}{l}2005 / \\
6\end{array}$ & $\begin{array}{l}2006 / \\
7^{\mathrm{a}}\end{array}$ & $\begin{array}{l}2007 / \\
8^{\mathrm{a}}\end{array}$ & $\begin{array}{l}2008 / \\
9^{a}\end{array}$ & $1997 / 98-1999 / 00$ & $1999 / 00-2005 / 6$ & $2005 / 6-2008 / 9^{a}$ \\
\hline $\begin{array}{l}\text { General government } \\
\text { services and } \\
\text { unallocatable } \\
\text { expenditure }\end{array}$ & 10.3 & 7.3 & 7.5 & 8 & 7.9 & 7.3 & 7.4 & 7.2 & 6.6 & 7.0 & 6.9 & 7.0 & -17.3 & 5.7 & 8.6 \\
\hline Protection services & 18.9 & 20.2 & 20.0 & 21 & 21.2 & 20.8 & 19.7 & 19.1 & 19.2 & 18.0 & 17.6 & 17.2 & -0.1 & 7.3 & 2.8 \\
\hline $\begin{array}{l}\text { Defence and } \\
\text { intelligence }\end{array}$ & 7.3 & 7.1 & 6.7 & 8 & 7.8 & 8.0 & 7.5 & 6.7 & 6.8 & 6.0 & 5.7 & 5.4 & -6.5 & 8.4 & -1.3 \\
\hline Police & 7.8 & 8.5 & 8.5 & 8 & 8.4 & 8.1 & 7.9 & 8.0 & 8.0 & 7.8 & 7.7 & 7.6 & 1.1 & 6.9 & 4.8 \\
\hline Prisons & 2.4 & 3.1 & 3.0 & 3 & 3.1 & 2.9 & 2.7 & 2.7 & 2.6 & 2.5 & 2.5 & 2.4 & 9.1 & 4.9 & 3.9 \\
\hline Social services & 59.9 & 61.2 & 60.5 & 59 & 57.3 & 57.4 & 58.7 & 59.2 & 59.3 & 59.2 & 59.5 & 59.5 & -2.6 & 7.8 & 6.8 \\
\hline Education & 27.2 & 26.9 & 26.6 & 26 & 24.7 & 23.5 & 23.2 & 22.5 & 21.7 & 20.9 & 20.9 & 20.7 & -4.1 & 3.9 & 5.0 \\
\hline Health & 13.9 & 14.6 & 14.3 & 14 & 13.7 & 13.0 & 12.8 & 12.6 & 12.4 & 12.1 & 12.0 & 11.8 & -1.6 & 5.2 & 4.8 \\
\hline $\begin{array}{l}\text { Social security } \\
\text { and welfare }\end{array}$ & 14.3 & 15.1 & 14.9 & 15 & 14.3 & 16.0 & 17.2 & 18.6 & 19.3 & 18.6 & 18.5 & 18.5 & -1.1 & 14.1 & 5.0 \\
\hline Housing & 4.2 & 3.9 & 2.1 & 2 & 1.9 & 2.1 & 2.0 & 1.9 & 2.0 & 2.1 & 2.3 & 2.3 & -31.0 & 6.8 & 11.3 \\
\hline $\begin{array}{l}\text { Community } \\
\text { development }\end{array}$ & 0.0 & 0.0 & 2.7 & 2 & 2.7 & 2.9 & 3.5 & 3.7 & 3.9 & 5.6 & 5.9 & 6.3 & & 16.5 & 25.7 \\
\hline Other & 0.4 & 0.7 & 0.0 & 0 & - & - & - & - & - & - & - & - & & & \\
\hline Economic services & 10.9 & 11.3 & 12.0 & 12 & 13.7 & 14.4 & 14.2 & 14.4 & 14.9 & 15.7 & 15.9 & 16.3 & 1.6 & 13.0 & 9.7 \\
\hline
\end{tabular}


$1997 / 1998 / 1999 / 2000 / 2002 / 2002 / 2003 / 2004 / 2005 / 2006 / 2007 / 2008 / 1997 / 98-1999 / 00$ 1999/00-2005/6 2005/6-2008/9a

$\begin{array}{llllllllllll}8 & 9 & 2000 & 1 & 3 & 3 & 4 & 5 & 6 & 7^{\mathrm{a}} & 8^{\mathrm{a}} & 9^{\mathrm{a}}\end{array}$

\begin{tabular}{|c|c|c|c|c|c|c|c|c|c|c|c|c|c|c|c|}
\hline $\begin{array}{l}\text { Water schemes } \\
\text { and related services }\end{array}$ & 1.5 & 1.7 & 1.6 & 2 & 1.8 & 1.8 & 1.8 & 1.7 & 1.6 & 1.6 & 1.6 & 1.7 & 0.6 & 8.0 & 9.5 \\
\hline Fuel and energy & 0.3 & 0.2 & 0.2 & 0 & 0.6 & 0.7 & 0.6 & 0.6 & 0.7 & 0.7 & 0.7 & 0.7 & -21.3 & 41.7 & 6.9 \\
\hline $\begin{array}{l}\text { Agriculture, forestry } \\
\text { and fishing }\end{array}$ & 2.2 & 2.3 & 2.2 & 2 & 2.1 & 2.0 & 2.1 & 2.1 & 2.2 & 2.5 & 2.6 & 2.5 & -3.4 & 8.5 & 11.3 \\
\hline $\begin{array}{l}\text { Mining, manufacturing } \\
\text { and construction }\end{array}$ & 0.7 & 0.7 & 0.7 & 1 & 0.5 & 0.4 & 0.5 & 0.5 & 0.5 & 0.5 & 0.5 & 0.5 & -2.8 & 4.4 & 3.5 \\
\hline $\begin{array}{l}\text { Transport and } \\
\text { communication }\end{array}$ & 4.4 & 4.6 & 4.9 & 5 & 5.2 & 5.4 & 5.2 & 5.3 & 5.2 & 6.1 & 6.2 & 6.4 & 1.8 & 9.5 & 14.3 \\
\hline $\begin{array}{l}\text { Other economic } \\
\text { services }\end{array}$ & 1.9 & 1.7 & 2.5 & 3 & 3.5 & 4.2 & 4.1 & 4.3 & 4.7 & 4.2 & 4.2 & 4.4 & 12.0 & 22.7 & 4.5 \\
\hline $\begin{array}{l}\text { Subtotal: votes } \\
\text { and statutory amounts }\end{array}$ & 100.0 & 100.0 & 100.0 & 100 & 100.0 & 100.0 & 100.0 & 100.0 & 100.0 & 100.0 & 100.0 & 100.0 & -3.0 & 8.2 & 6.6 \\
\hline $\begin{array}{l}\text { Total non-interest } \\
\text { expenditure }\end{array}$ & & & & & & & & & & & & & -3.0 & 8.2 & 7.1 \\
\hline Interest & & & & & & & & & & & & & -0.2 & -4.5 & -1.6 \\
\hline $\begin{array}{l}\text { Total consolidated } \\
\text { expenditure }\end{array}$ & & & & & & & & & & & & & -2.5 & 6.2 & 6.2 \\
\hline
\end{tabular}

Source: National Treasury (2006) and other Budget Reviews. Real annual growth rates obtained using CPIX deflator $(2000=100)$. CPIX projections for the MTEF period based on National Treasury $(2005 a, p .12)$.

${ }^{\mathrm{a}}$ MTEF period. 
Cape spent only $37 \%$ of available funds, and the Northern Cape, $65 \%$ (National Treasury, 2003, p. 162). This inability to spend resulted in rollovers, with some $71 \%$ of housing funds rolled over in $1995 / 6,20 \%$ in $2000 / 1$ and $12 \%$ in $2001 / 2$ (National Treasury, 2003 , p. 163). Although $1,614,512$ houses had been built by the end of 2003/4 (National Treasury, 2004a, p. 125), the rate of delivery has been insufficient to meet a housing backlog estimated at 2,406,747 units using Census 2001 data (National Treasury, 2003, p. 127). Moreover, a rising number of low-income households is increasing the backlog (National Treasury, 2004b, p. 127). With falling household sizes (3.8 people on average in 2001 compared with 4.5 in 1996), the number of households increased by $4.7 \%$ per annum during 1996-2001, faster than the annual population growth rate of $2.1 \%$. Given the Grootboom judgement of October $2004^{16}$ by the Constitutional Court of South Africa, which clarified the test for 'reasonableness for evaluating progressive realisation' of housing provision, this situation is a cause for concern.

The divergence of private and social benefits is largest in basic education. The social rate of return to primary education is generally far higher than that of post-primary education in many developing countries. South Africa is one of the highest spenders on education among middle-income countries in terms of GDP per capita and as a percentage of total expenditure. Nevertheless, the quality of the educational outcomes is significantly inferior to comparable developing countries. This is partly explained by substantial infrastructure backlogs, inadequate access to learner support materials, unqualified teachers (especially in the crucial areas of mathematics and science) and low funding of adult basic education and early childhood development. ${ }^{17}$ Improved quality of education is reflected in raised secondary school certificate pass rates and university entrance passes, according to the Department of Education (2004, p. 7). The matriculation pass rate indeed increased from 47 to $71 \%$ between 1997 and 2004 (National Treasury, 2005b). However, mathematics higher grade passes are probably a better indication of educational quality. Although increasing marginally, these have remained low, especially in provinces such as the Eastern Cape (4\%) and Limpopo (5\%). South Africa has participated

16 Republic of South Africa versus Grootboom, Case no. CCT 11/00.

17 Similar types of constraints occur within the health sector. 
in three cross-national studies of quality and achievement, ${ }^{18}$ with disconcerting results. In the Third International Mathematics and Science Study, South Africa scored below the international average for the 38 countries that participated in the study; for both mathematics and science, it scored well below countries with comparable economic and education profiles, such as Tunisia, Chile and the Philippines (Department of Education, 2004).

Reduced disparities in funding allocation appear not to have reduced the variability of educational outcomes across provinces. Van der Berg (2007) finds that large differentials in performance among black schools cannot be attributed to socioeconomic background or teaching resources, but rather to school management and the functioning of the schooling system. He concludes that additional fiscal resources on their own can only make a limited contribution to enhancing educational outcomes. Ensuring that poor schools have access to qualified teachers and better school management is not merely a fiscal problem, but a social problem with complex dimensions of location (rural/urban, city/township), language, race and union opposition to salary differentiation (Van der Berg (2007)).

\section{Conclusion}

South Africa has overcome adverse initial conditions and achieved a remarkable fiscal transformation over the last decade through adopting durable, credible and well-coordinated reforms, outlined in earlier sections of this paper. Allsopp and Vines (2005) maintain that there is an active role for fiscal policy in flexible inflation-targeting regimes in setting the policy mix and in managing shocks and imbalances. The fiscal-monetary policy mix in South Africa has created an environment of macroeconomic stability conducive to future growth. Inflation targeting was successfully introduced and the restrained fiscal stance and improved debt management have helped support a low inflation monetary policy. Consumer price inflation fell from double-digit figures in the 1990s to well within the target range from late 2003. Lower and more predictable inflation and interest rates have helped contain business costs,

18 The Third International Mathematics and Science Study (Repeat), or TIMSS (R), The Monitoring of Learning Achievement (MLA) project and The Southern African Consortium for Monitoring Quality (SACMEQ). 
while greater fiscal and monetary policy credibility and transparency have reduced uncertainty in the economy. South Africa's international economic standing has been enhanced, evidenced by reduced sovereign risk spreads and improved debt ratings.

There are other complementary fiscal measures on households that could facilitate the work of the central bank. An example is well-designed property and land taxes. These could help contain the sharply rising debt-to-income and consumption-to-income ratios under liberalised credit markets in South Africa, partly driven by rising house and land prices (Aron and Muellbauer, 2005). Another instance is redressing the recent underfunding of Statistics South Africa by the Treasury owing to cost-cutting. This has proved misguided and costly in terms of reliable historical data on which to base monetary policy formulation (though this issue is belatedly receiving attention).

The undoubted macrostability gains contrast sharply with poor delivery at the microeconomic level. The fiscal strategy underpinning the GEAR macro programme was based on two major objectives. The first was a deficit reduction strategy, aimed at curtailing the growth of interest obligations, combating inflation and freeing up resources for investment in infrastructure and human capital. The second pillar was the budget reform programme to strengthen redistribution. The underlying rationale seems to have been that even though the quantum of expenditure would decline, this would be offset by the enhanced equity, efficiency and effectiveness in the way these resources were used. While the former objective has been attained, the latter has, at best, only been partially achieved. International reform experience cautions that the benefits of budget reforms such as the MTEF, performance-based budgeting and accruals only manifest themselves over an eight-to-ten-year horizon. The sheer magnitude of the budget reform project was probably underestimated by the incoming government, both because the degree and scope of dysfunction in the inherited Apartheid fiscal machinery could not have been fully ascertained then, and given the magnitude of the economic development problems facing South Africa. The timing and synchronization of the costs and benefits of these two strategies have also proved problematic. Deficit reduction created immediate, concentrated costs to society, with its (uncertain) benefits only to be realised in the future. There were also substantial set-up costs associated with 
the budget reform, ${ }^{19}$ and thereafter, incremental maintenance costs. The near term adjustment has therefore been painful: the full costs of deficit reduction but few of its benefits; some of the costs of budget reform, with diffused benefits expected mainly towards the end of its implementation.

The hard-won sustainability of fiscal policy might be threatened in the future. Reduced revenue collection windfalls coupled with fiscal risk from the existing social security entitlements will have to be carefully managed. In addition, mediocre improvements in the quality and scope of actual service delivery and the continuing dearth of management capacity for delivery, in a context of an increasing number of households, the ravages of HIV/AIDS, improvements in economic growth insufficient to substantially lower unemployment and persisting poverty, inequality and deprivation, could mean the government will face increasing pressure to extend existing cash-based entitlements. Lobbying in recent years for the proposed introduction of a universal Basic Income Grant is a case in point. Political sustainability of policies is at least as important as fiscal sustainability. Further, a long-term decline in infrastructure investment and capital stock is only belatedly receiving attention. The challenge for South Africa is to increase social and infrastructure expenditure at a sustainable rate and to enhance the quality of service delivery, to avoid undermining the impressive fiscal stability gains at the macroeconomic level.

\section{Acknowledgements}

A debt of gratitude is owed to Estian Calitz, Stellenbosch University, John Muellbauer, Oxford University, and an anonymous referee, whose comments on an earlier draft have improved this paper; and to participants in the joint CSAE-Stellenbosch University conference South African Economic Policy Under Democracy: a 10 Year Review (2728 October 2005). Janine Aron is grateful for research funding from the Department for International Development (grant R8311). The

19 These include design and implementation of promulgation of new legislative frameworks, new accounting and management information systems, other IT infrastructure such as networks, creation of new institutional structures (e.g., audit committees, risk management committees), recruitment of additional personnel, training of existing and new personnel, systems integration costs (marrying financial and non-financial information) and other compliance costs to public sector organisations. 
UK Department for International Development (DFID) supports policies, programmes and projects to promote international development. DFID provided funds for this study as part of that objective but the views and opinions expressed are those of the authors alone.

\section{References}

Abedian, I. (1998) 'Fiscal Policy and Economic Growth', in I. Abedian and B. Standish (eds), Economic Growth in South Africa: Selected Policy Issues, Cape Town: Oxford University Press. Ajam, T. and C. Murray (2004) 'The Courts, Socio-economic Rights and Intergovernmental Fiscal Relations', paper presented at the Financial and Fiscal Conference 'Consolidation for Equity', Cape Town, 12-14 August 2004.

Alesina, A. and S. Ardagna (1998) 'Tales of Fiscal Adjustment', Economic Policy, 27: 487-546.

Alesina, A., R. Perotti and J. Tavares (1998) 'The Political Economy of Fiscal Adjustments', Brookings Papers on Economic Activity, 1: 197-266.

Allsopp, C. and D. Vines (2005) 'The Macroeconomic Role of Fiscal Policy', Oxford Review of Economic Policy, 21 (4): 485-508.

Aron, J. and J. Muellbauer (2005) 'Monetary Policy, Macro-stability and Growth: South Africa's Recent Experience and Lessons', World Economics, 6 (4): 123-47.

Aron, J. and J. Muellbauer (2007a) 'Transparency, Credibility and Predictability of Monetary Policy in South Africa', paper presented at the Bank of England/Cornell University workshop on "New developments in monetary policy in emerging market economics", Bank of England, 17-18 July, 2007.

Aron, J. and J. Muellbauer (2007b) 'Review of Monetary Policy in South Africa since 1994', this volume.

Black, P., K. Siebrits and T. van der Merwe (2005) 'Public Expenditure and Growth', in Black, Calitz and associates (eds), Public Economics, Third Edition, Oxford University Press.

Bogetić, Z. and J.W. Fedderke (2006) 'Forecasting Investment Needs in South Africa's Electricity and Telecom Sectors', South African Journal of Economics, 74 (3): 557-74.

Breton, A. (1996) Competitive Governments: An Economic Theory of Politics and Public Finance, Toronto: Cambridge University Press. 
Calitz, E. (2000) 'Fiscal Implications of the Economic Globalisation of South Africa', South African Journal of Economics, 68 (4): 564-606.

Calitz, E. and K. Siebrits (2003) 'Fiscal Policy in the 1990s', South African Journal of Economic History, 18 (1-2): 50-75.

Department of Education (2004) 'The Development of Education', Country Report of South Africa, 47th International Conference on Education, 8-11 September 2004.

Department of Finance (1997) Budget Review 1997, Pretoria: Government Printers.

Department of Finance (1998) Budget Review 1998, Pretoria: Government Printers.

Du Plessis, S. and B. Smit (2007) 'South Africa's Growth Revival after 1994', this volume.

Fedderke, J.W. (2004) 'Investment in Fixed Capital Stock: Testing for the Impact of Sectoral and Systematic Uncertainty', Oxford Bulletin of Economics and Statistics, 66 (2): 165-87.

Fedderke, J.W. and W. Liu (2002) 'Modelling the Determinants of Capital Flows and Capital Flight: with an Application to South African Data from 1960 to 1995', Economic Modelling, 19 (3): 419-44.

Fedderke, J.W. and A.T. Romm (2005) 'Growth Impact and Determinants of Foreign Direct Investment into South Africa, 1956-2003', Economic Modelling, 23 (5): 738-60.

Fielding, D. (2000) 'Investment under Credit Rationing and Uncertainty: Evidence from South Africa', Journal of African Economies, 9 (2): 189-212.

Groenewegen, P.D. (1979) 'Federalism', in A. Patience and B. Head (eds), From Whitlam to Fraser, Melbourne: Oxford University Press.

Hines, J.R. (2006) 'Will Social Welfare Expenditures Survive Tax Competition?, Oxford Review of Economic Policy, 22 (3): 330-48.

Horton, M. (2005) 'Role of Fiscal Policy in Stabilization and Poverty Alleviation', in N. Nowak and L. Ricci (eds), Post-Apartheid South Africa, Chapter 2, International Monetary Fund.

Kopits, G. and S. Symansky (1998) 'Fiscal Policy Rules', IMF Occasional Paper 162, International Monetary Fund, Washington DC.

Mackenzie, G.A., W.H. Orsmond and P. Gerson (1997) 'The Composition of Fiscal Adjustment and Growth: Lessons from 
Fiscal Reforms in Eight Economies', IMF Occasional Paper 149, Washington DC: International Monetary Fund.

Meltzer, A.H. and Richard, S.F. (1981) 'A Rational Theory of the Size of Government', Journal of Political Economy, 89 (5): 914-27.

Momoniat, I. (2002) 'Fiscal Decentralisation in South Africa: a Practitioner's Perspective', mimeo, South Africa: National Treasury.

National Treasury (2003) Intergovernmental Fiscal Review, Pretoria: Government Printers.

National Treasury (2004a) Budget Review 2004, Pretoria: Government Printers.

National Treasury (2004b) Trends in Intergovernmental Finance, 2000/ 01-2006/7, Pretoria: Government Printers.

National Treasury (2005a) Budget Review 2005, Pretoria: Government Printers.

National Treasury (2005b) Provincial Budgets and Expenditure Review 2001/02-2007/8, Pretoria: Government Printers.

National Treasury (2006) Budget Review 2006, Pretoria: Government Printers.

Perkins, P., J.W. Fedderke and J. Luiz (2005) 'An Analysis of Economic Infrastructure Investment in South Africa', South African Journal of Economics, 73 (2): 211-28.

Rao, M.G. and N. Singh (1999) 'The Assignment of Taxes and Expenditures in India', CREDPR Working Paper, March 1999, Economics Department, University of California Santa Cruz.

Shah, A. (1994) 'The Reform of Intergovernmental Fiscal Relations in Developing and Emerging Market Economies', Policy and Research Series 23, Washington DC: World Bank.

Siebrits, F.K. and Calitz, E. (2004) 'Should South Africa Adopt Numerical Rules', South African Journal of Economics, 72 (4): 759-70.

Swanepoel, J.A. and Schoeman, N.J. (2003) 'Countercyclical Fiscal Policy in South Africa: Role and Impact of Automatic Fiscal Stabilisers', South African Journal of Economic and Management Studies, 6 (4): 802-22.

Van der Berg, S. (2001) 'Trends in Racial Fiscal Incidence in South Africa', South African Journal of Economics, 69 (2): 243-28.

Van der Berg, S. (2007) 'Apartheid's Enduring Legacy: Inequalities in Education', this volume. 